Omni-Akuatika, 13 (1): 110-116, 2017
ISSN: 1858-3873 print / 2476-9347 online
Research Article

\title{
Correlation Between Paddle Wheel Operation Time with Microalgae (Nannochloropsis sp.) Growth Rate and Lipid Contents in Open Raceway Ponds
}

\author{
Welmar Olfan Basten Barat ${ }^{\left.{ }^{*}\right)}$, Mujizat Kawaroe ${ }^{1,2)}$, Dietriech G Bengen ${ }^{1)}$ \\ ${ }^{1 *}$ Department of Marine Science and Technology, Faculty of Fisheries and Marine Science, Bogor \\ Agricultural University, Jl. Agatis No.1 Dramaga, Bogor, 16680 Indonesia \\ ${ }^{2)}$ Surfactant and Bioenergy Research Center (SBRC-LPPM), Bogor Agricultural University, Bogor, \\ 16143 Indonesia
}

*Corresponding author:olfan_basten_barat@yahoo.com

Received 27 October 2016; Accepted 17 May 2017; Available online 31 May 2017

\begin{abstract}
Nannochloropsis sp. is one of microalgaes species with high lipid content, so it has great potential to be used as the source of biofuel. One of the microalgae cultivation system in mass scale is open raceway ponds. Problems faced in microalgae cultivation with open raceway ponds system are low productivity and the high production cost, especially high electrical energy for operating paddle wheel machine. This research studies about efficiency and effectiveness level of the cultivation system with open raceway ponds through the analysis of correlation between operational duration of the paddle wheel with growth rate and lipid content from Nannochloropsis sp.. The highest density is $530 \times 10^{6}$ cell $/ \mathrm{ml}$ found in treatment of $45 \mathrm{~min} / \mathrm{h}$. The highest growth rate is $0,45 /$ days Which also found in the treatment of $45 \mathrm{~min} / \mathrm{h}$ but the treatment $45 \mathrm{~min} / \mathrm{h}$ is only able to survive until 12 days. The highest productivity of dry biomass is $0,25 \mathrm{~g} / \mathrm{L} /$ day found in treatment of $45 \mathrm{~min} / \mathrm{h}$. Meanwhile, the highest lipid content contained on treatment $15 \mathrm{~min} / \mathrm{h}$ is $5,19 \%$ dry cell weight (DCW). Dominant fatty acids for all treatments are palmitic acids. The best treatment related to the use of the paddle wheel machine is $15 \mathrm{~min} / \mathrm{h}$.
\end{abstract}

Keyword: Growth, lipid, Nannochloropsis sp., open raceway ponds, paddle wheel

\section{Introduction}

The research development of renewable energy has increasingly conducted to answer the challenges of the energy crisis. Therefore, the effort of providing alternative fuels becomes very important, including through biofuels. Research development of raw material has been conducted a lot such as crude palm oil (CPO) from Palm oil, corn, soybean, canola, jatropha, coconut, and microalgae with production capacity of the plant as much as 172 litres per hectare of corn, soy 446 litres per hectare, olive oil 1190 liters per hectare, a distance of 1892 liters per hectare, nuts 2689 liters per hectare, Palm 5.950 liters per hectare, and microalgae 58.700 liters per hectare (Chisti, 2007).

Microalgae is one of the best solution to be the feedstock for alternative energy (biofuels). Microalgae is the marine plants that is able to grow up in a very short time. Microalgae Nannochloropsis sp. is one of microalgae species that has a high lipid content. Nannochloropsis sp. is also able to grow quickly and have a high level of tolerance towards environmental pressure. Some environmental conditions that can affect the microalgae growth among are temperatures, the quality and quantity of nutrients, light intensity, the degree of acidity $(\mathrm{pH})$, aeration (source of $\mathrm{CO}_{2}$ ) and salinity (Kawaroe et al., 2010).

The problem faced at this time is the mass scale cultivation system, such as the system of open raceway ponds cultivation, where operating costs are still high especially electrical energy needs, while the productivity is still low. Use of the paddle wheel machine to perform the stirring (mixing) with the aim of avoiding deposition and creates current in the cultivation media for nutrient equalization as well as aeration that are expected to optimize the photosynthesis process becomes one factor that caused the high electrical energy needs. Therefore, this study was conducted to analyze the relation between operational duration of the paddle wheel and the growth rate and lipid content, the character of fatty acids, and the efficiency and effectiveness level 
of the paddle wheel machine use. So, the results from this research can be used as the standard for the paddle wheel engines that is capable for suppressing the production costs and the electric power need, as well as the increase in growth rate and lipid content.

\section{Materials and Methods}

\section{Cultivation}

Microalgae Nannochloropsis sp. was cultivated in Algae laboratory at Marine Field Station (SLK - IPB), Sukabumi. This research began in February until May 2016. The cultivation of mikroalgae was conducted in several stages: indoor cultivation (laboratory scale), and then after seven days period maintenance, semi - outdoor cultivation for the adaptation purpose prior to cultivation in the medium open raceway ponds. After maintenance was conducted during seven days in semi - outdoor scale, then continued to the cultivation in small open raceway ponds (volume of 8,000 liters). Cultivation in a small open raceway ponds were intended for microalgae adaptation and seedlings. Comparison between the strain volume and sterile water is $1: 10$. Cultivation in large open raceway ponds (volume: 80.000 liters) was carried out for 21 days.

\section{Specific growth rate and density measurement}

Measurement of the specific growth rate using microscope was conducted every day with three replications. The observations are calculated with the equation of Wood et al. (2005):

$$
K=\frac{n^{N t}-l n^{N_{0}}}{t-t_{0}}
$$

Description:

$\mathrm{K}=$ Specific growth rate;

$\mathrm{N}=$ density of the cells at the time $-\mathrm{t}$;

$\mathrm{N}_{0}=$ Cell density at the beginning of cultivation

$\mathrm{T}=$ Observation time;

$t_{0}=$ the start time of cultivation

Density measurements using haemocytometer by the equation (Kawaroe et al. 2010):

$$
N=\left(\frac{n}{4}\right) \times 10^{6} .
$$

\section{Description:}

$\mathrm{N}=$ Microalgae Density (cells $/ \mathrm{ml}$ );

$\mathrm{n}=$ number of microalgae observed
Determination of total lipids and fatty acids

Dry biomass of microalgae Nannochloropsis sp. were extracted at Laboratory of Surfactant and Bioenergy Research Center (SBRC - IPB) Baranang Siang, Bogor. Determination of lipid levels was conducted through the extraction of dry biomass from $15 \mathrm{gr}$ of microalgae Nannochloropsis sp. and $250 \mathrm{ml}$ solution of $\mathrm{n}$ hexane. Each sample was extracted three times. Fat content and lipid productivity is calculated by the following equation:

$$
\begin{aligned}
L_{c} & =\frac{L W}{A W} \times 100 \ldots \ldots \\
L_{p} & =\frac{m_{t} \times L_{c}}{\text { Day }} \times 100 .
\end{aligned}
$$

\section{Description:}

Lc $($ Lipid Content $)=$ Fat Content $(/ \%$ DCW $)$

LW = Lipid Weight extracted $(\mathrm{g})$;

$\mathrm{AW}=$ Dry weight biomass of algae (gr);

$\mathrm{LP}=$ Lipids productivity $(\mathrm{mg} / \mathrm{l} / \mathrm{h})$;

Day $=$ time of cultivation (d).

Analysis of fatty acids were determined by using GC-MS with Omegawax 250 polyethylene glycol capillary column $(30 \mathrm{~m}$ length, diameter, $0.25 \mathrm{~mm}$; thickness $0.25 \mu \mathrm{m}$ film), using methods of Khozin-Goldberg et al. (2005).

\section{Statistic analysis}

Growth rate and lipid content were statistically analyzed using Analysis (ANOVA) with 95\% confidence interval (Steel \& Torrie, 1989). The equation is as follows:

$Y i j=\mu+\varepsilon ́ i j+T i$.

Description:

Yij = Treatment type of organic material (i) in Deuteronomy to-jthe middle value of

$\mu=$ Common middle value

$\mathrm{Ti}=$ added value due to the treatment of the different types of organic materials (i)

Éij=error treatment experiment on the treatment of the different types of organic materials (i) and repeated to-j.

To determine the influence of Paddle wheel machine spin duration and the growth rate and lipid content of microalgae (Nannochloropsis sp.), the further Tukey Test is needed (Mattjik \& Sumertajaya, 2002) with the following equation: 
$B N J=q_{\alpha ; p ; d b g} ; S \gamma$

Description:

$B N J=$ Honest Significant Difference

$\mathrm{P}=$ Treatment

$d b_{g}=$ degrees of error-free

$S \gamma=$ Mean standard error deviation

$\boldsymbol{q}_{\alpha ; p ; d b_{g}=\text { Tukey table values on the real level }}$ $\alpha$

This research was conducted with the treatment as follows:

Control $=$ Without treatment of Paddle wheel machine

$15 \mathrm{~min} / \mathrm{h}=$ Machine paddle wheel operated for 15 minutes per hour

$30 \mathrm{~min} / \mathrm{h}=$ Machine paddle wheel operated for 30 minutes per hour

$45 \mathrm{~min} / \mathrm{h}=$ Machine paddle wheel operated for 45 minutes per hour.

Mixing with paddle wheel machine performed during 10 hours per day, which is at $8: 00$ to 17:00 pm.

\section{Results and Discussion}

\section{Density and specific growth rate}

The highest density frome all treatment was found in the treatment $45 \mathrm{~min} / \mathrm{h}$ on day -6 with number of microalgae $530 \times 10^{6} \mathrm{cell} / \mathrm{ml}$. For the control and treatment of $45 \mathrm{~min} / \mathrm{h}$, the growth stopped until on day -9 and to day -12 , but there were difference in treatment of $15 \mathrm{~min} / \mathrm{h}$ and $30 \mathrm{~min} / \mathrm{h}$, where the growth continued until the end of observation on day 21 (Figure 1).

This condition is suspected during the cultivation, the controls were not carried out with paddle wheel stirring (mixing), so deposition occurred at low level of sunlight penetration into the waters of the column led to the no optimal photosynthesis process also has impacted the immediate death. The results of kawaroe Kawaroe et al. (2015) showed that the highest density of Nannochloropsis sp. in the heterotrophic cultivation system is 74.415 ind $/ \mathrm{ml}$. Conditions that occurrred in the treatment of $45 \mathrm{~min} / \mathrm{h}$ system result to the increased rate of water movement that exceed the optimum limits for microalgae growth in cultivation system of open raceway ponds, and caused many waves and bubbles (ripple) which results in refraction of sunlight into the column. The light intensity is usually decreasing sharply due to cell absorption, scattering, and reflection among the microorganism cells as well as the cultivation of media elements (Vincenti \& Kruger, 1965; Cassano et al., 1995). It was also aligned with Gudin \& Chaumont (1991), that shearing stress or stress caused by air bubbles can cause unbalanced cell growth, cell damage, and even death.

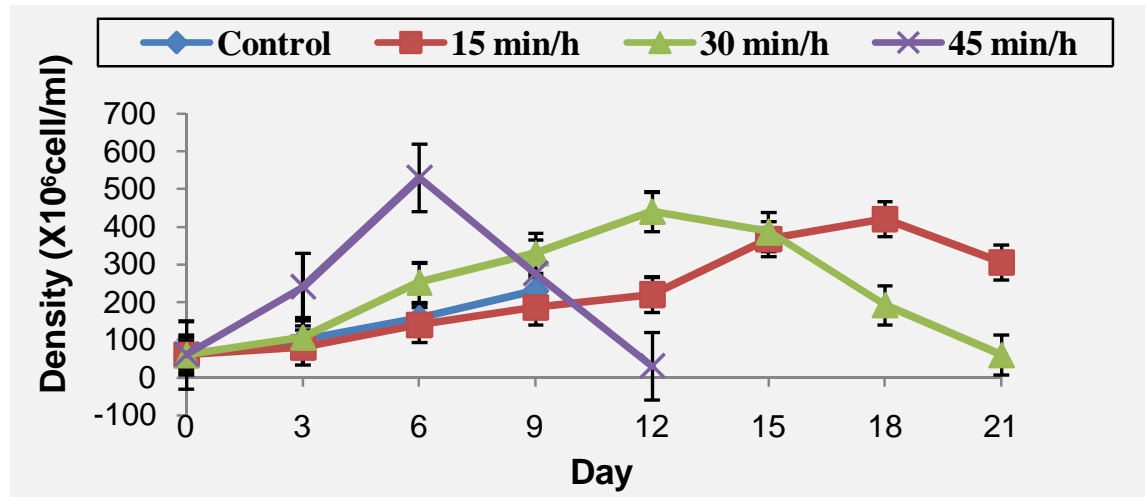

Figure 1. Density of microalgae Nannpchloropsis sp. for 21 days cultivation 


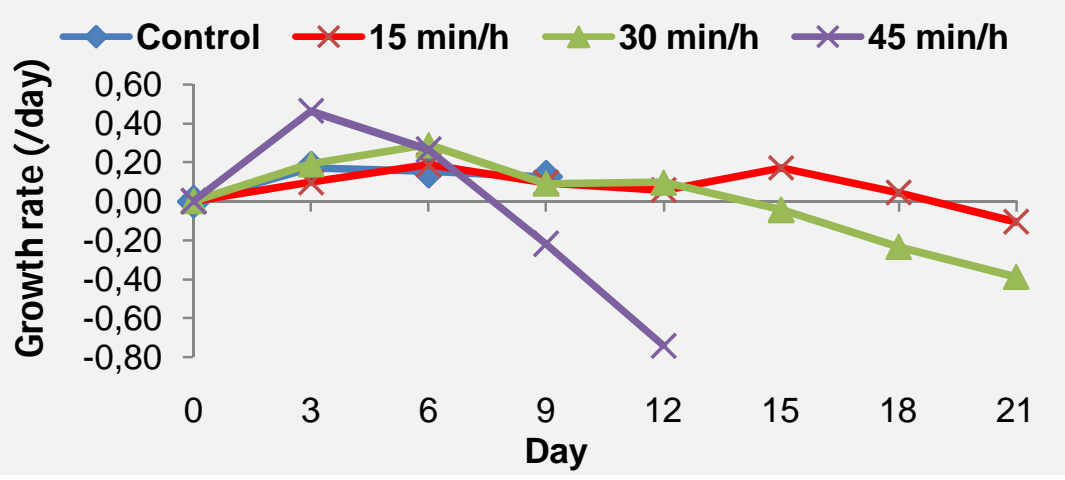

Figure 2. Microalgae growth rate graphic of Nannochloropsis sp. for 21 days cultivation

The highest growth rate occurred in the treatment $45 \mathrm{~min} / \mathrm{h}$ was on day -3 of $0.46 /$ day, but on the day -12 it decreased precipitously to $-0.74 /$ day. All treatment has decreasing growth rate up to the minus curves as in Figure 2. spectively, i.e. $15 \mathrm{~min} / \mathrm{h}=-0.11 /$ day, $30 \mathrm{~min} / \mathrm{h}=-$ $0.39 /$ day, and $45 \mathrm{~min} / \mathrm{h}=-0.74 /$ day. At the treatment $15 \mathrm{~min} / \mathrm{h}$ and $30 \mathrm{~min} / \mathrm{h}$, they almost had the same growth pattern where the phase lag was on day -3 ,the logarithmic phase occur at day -6 , and stationary phase was at day -9 and day -12 . The pattern of growth was influenced by the duration of rotation conducted in 15 and 30 Minutes per hour that did not change the flow speed significantly, so there was no as waves, and bubbles that were able to refract the sunlight. In Figure 2, it can also be seen that Nannochloropsis sp. was still able to survive during 21 days of maintenance, although the growth rate has only been optimized on day -15 . The success of Nannochloropsis sp. in treatment $15 \mathrm{~min} / \mathrm{h}$ and $30 \mathrm{~min} / \mathrm{h}$ to survive until the $21 \mathrm{st}$ day was suspected on the stirring using paddle wheel machine that did not give the opportunity for microalgae to experience the deposition.

The lipid content of biomass and productivity microalgae Nannochloropsis sp.

The highest biomass productivity overall during the observation time was the treatment of $45 \mathrm{~min} / \mathrm{h}$ at day -6 of $0,25 \mathrm{~g} / \mathrm{L} /$ day, while the lowest value was also located at the same treatment at day -12 of $0,01 \mathrm{~g} / \mathrm{L} /$ day (Figure 3 ). The results of this research on biomass productivity has linear relationship with the growth rate.

The highest lipid results of all treatments was at day -9 at the treatment of $15 \mathrm{~min} / \mathrm{h}$ of $5,19 \% \mathrm{DCW}$ and the lowest was at day -3 in treatment $30 \mathrm{~min} / \mathrm{h}$, of $0,38 \%$ DCW (Figure 4). According to Kawaroe et al. (2010), total lipid content of microalgae ranges from $1 \%$ to $70 \%$ of the DCW.

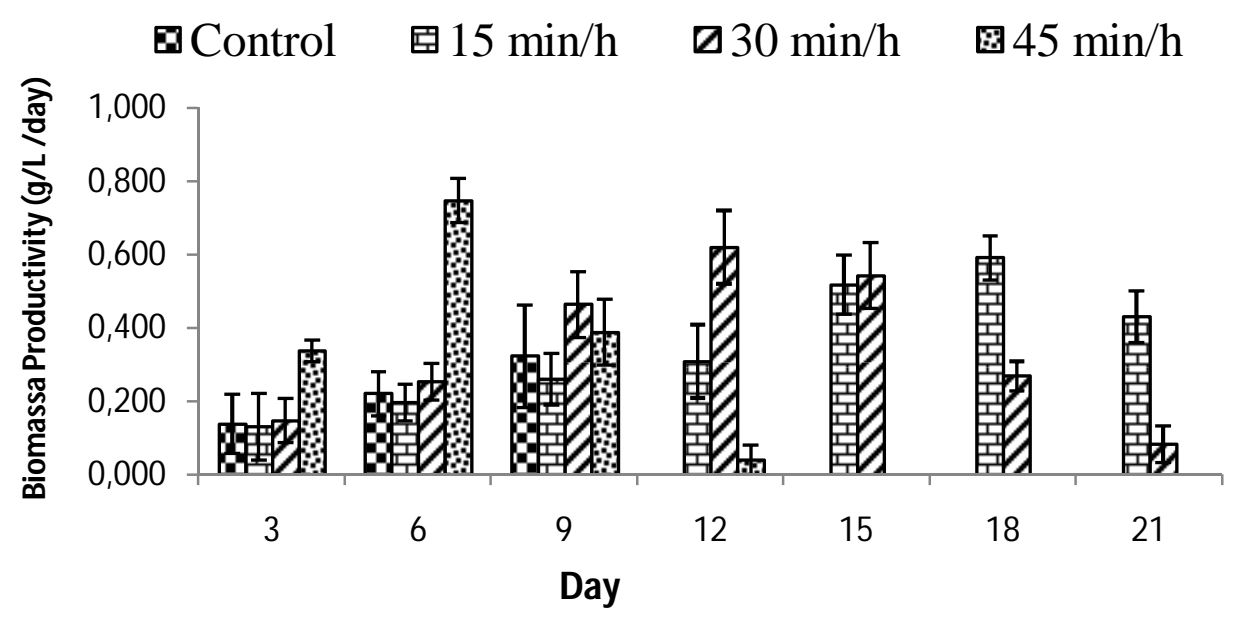

Figure 3. Biomass productivity of microalgae Nannochloropsis sp. for 21 days cultivation 


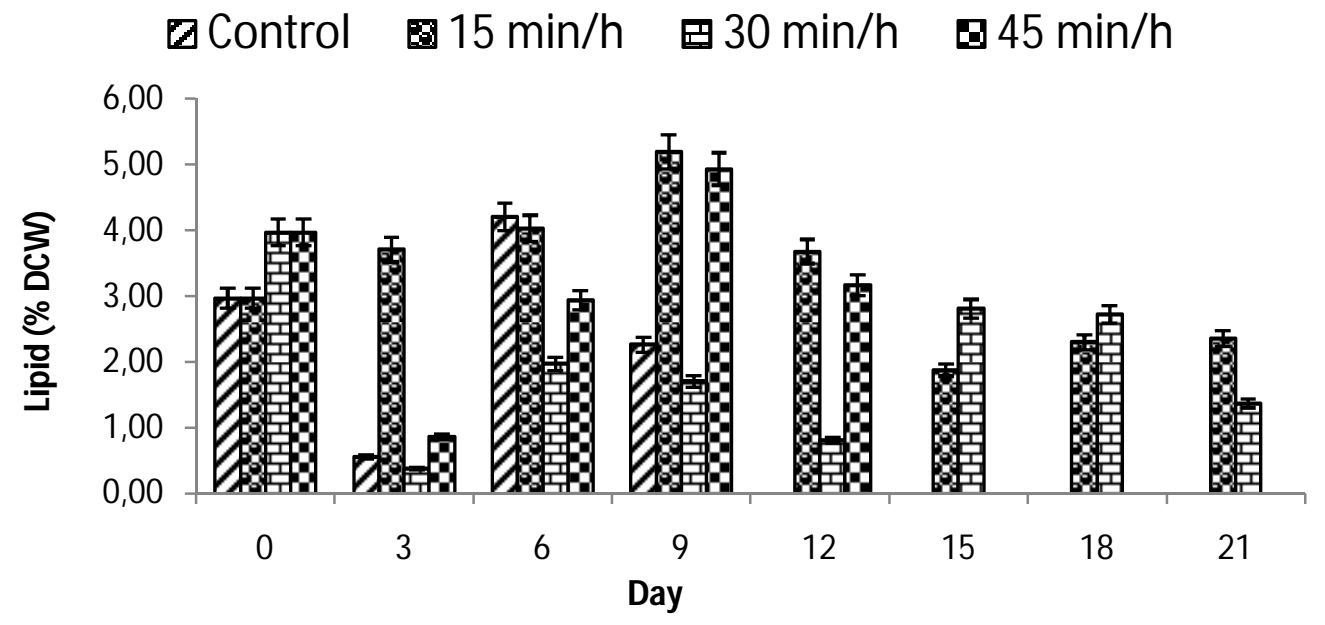

Figure 4. Lipid content of microalgae Nannochloropsis sp. for 21 days cultivation

Small lipid number produced in this research may be caused by some environmental factors along of cultivation time. The effect of duration treatment using paddle wheel did not show direct to the microalgae biosynthesis in increasing the lipid content in microalgae cell. Therefore, it was estimated that there are other factors that holds an important role in production such as nitrogen.

According to $\mathrm{Hu}$ et al., 2008; Klok et al., 2013, lipid on some microalgae are highly dependent on environmental conditions along cultivation. If the microalgae cells grow old or experience stress, then it will affect the lipids content. When the statement was connnected with this research, then theory of $\mathrm{Hu}$ et al., 2008, should be considered where the nitrogen existence along cultivation will affect the lipid content and TAGs. It can also be clarified by Kawaroe et al. (2010), where the existence of macro and micro nutrients will affect the content of proteins, carbohydrates and fats (lipids) of microalgae. Nutrients that often become the limiting factor in microalgae cultivation is nitrogen $(\mathrm{N})$ and phospore $(\mathrm{P})$.

\section{Fatty acids}

Overall, the fatty acid variation for the control and all treatments almost have the same pattern for the two highest values of fatty acids, which is Palmitic acid and myristic acid (Table 1). These results is in accordance to Kawaroe et al. (2010), that the dominant fatty acids on microalgae Nannochloropsis sp. is palmitic acid. Based on the fatty acids analysis in this research, the percentage of fatty acids microalgae Nannochloropsis sp. reached $50 \%$, in line with previous research, that the fatty acids range of in Nannochloropsis sp. is between 30\% - 50,4\% (Chiu et al., 2009). Saturated fatty acids composition in this research in all treatment was more than $50 \%$ of all fatty acids, it is also proved that microalgae Nannochloropsis sp. is potential to be used as biodiesel feedstock.

Table 1. The composition of the fatty acid content (\% of total lipids) Nannochloropsis sp. cultivation period for 21 days on all treatments

\begin{tabular}{lrrrr}
\hline \multicolumn{4}{c}{ Fatty Acid } \\
\hline \multicolumn{1}{c}{ Compound } & \multicolumn{2}{c}{ Area (\% total lipid) } \\
Laurat & Control & $\mathbf{1 5} \mathbf{m i n} / \mathbf{h}$ & $\mathbf{3 0 m i n} \mathbf{h}$ & $\mathbf{4 5 m i n / h}$ \\
Miristic & 0.15 & 0.13 & - & 0.15 \\
Stearat & 14.33 & 14.70 & 4.55 & 13.98 \\
Palmitic & 3.02 & 4.19 & 0.28 & 0.13 \\
Linoleat & 50.81 & 31.61 & 27.79 & 48.38 \\
Oleat & 9.95 & 2.93 & 0.92 & 2.15 \\
Arachidonat & 1.16 & 6.80 & 5.36 & 7.18 \\
\hline
\end{tabular}

Physical and chemical media parameters (temperature, salinity, dissolved oxygen, and the degree of acidity) 
Based on the results of physical and chemical parameter observations in cultivation media, the temperature range from $27-31^{\circ} \mathrm{C}$. The lowest temperature occurred uniformly for all treatment: $27^{\circ} \mathrm{C}$ on day -3 , this is caused by the rainfall. While the highest temperature was $31^{\circ} \mathrm{C}$, and it happens randomly to all treatment. Overall, the range of temperature are still in the optimum range for microalgae growth. According to Reynolds. (1990), the optimal temperature for growth mikroalga is $25-40^{\circ} \mathrm{C}$. Salinity ranges between $28-31 \%$. Salinity values uniformly on first day of cultivation: $31 \%$, but decreased to $28 \%$ for all treatments, it was also because of rain. The salinity range, was still in tolerance for microalgae optimal growth. Vasquez-Duhalt \& Arredondo-Vega (1991), mentioneds that the optimum salinity range is $25-35 \%$.

The degree of acidity $(\mathrm{pH})$ for research was in the range $8-8.2$. $\mathrm{pH}$ range was still at the optimum range for microalgae growth. The average $\mathrm{pH}$ of culture for most microalgae species is between $7-9$, with the $\mathrm{pH}$ optimum ranges between 8,2-8,7 (Lavens \& Sorgeloos, 1996). $\mathrm{pH}$ value in this research is relatively stable. This condition can be used as one reference that the presence of $\mathrm{CO}_{2}$ in water is stable. Measurement of dissolved oxygen (DO) in the research is aimed to suspect the presence of $\mathrm{CO}_{2}$ in the water. Based on a relatively stable $\mathrm{DO}$, and the range of normal $\mathrm{DO}$, then it is estimated that the presence of $\mathrm{CO}_{2}$ was also stable in cultivation media. The presence of $\mathrm{CO}_{2}$ in closed waters, particularly (open raceway ponds) will give effect on $\mathrm{pH}$.

\section{Statistical analysis}

The results of statistical analysis showed that the duration of paddle wheel machine use has no real effect against the growth rate and lipid content of microalgae Nannochloropsis sp.. A similar case also happened in Kawaroe et al. (2000), that the cultivation system of open raceway ponds does not influence the growth rate. Based on the results of the statistical tests, it can be said that the duration length of paddle wheel machine does not influence directly, but gives a great contribution towards optimization of the photosynthesis process. This can be proved through different growth rate results in each treatment, where the highest growth rate is found in the treatment of $45 \mathrm{~min} / \mathrm{h}$ of $0.46 /$ day. Duration length of paddle wheel operation also affects the survival rate of microalgae, where the growth rate shows that the microalgae in control and $45 \mathrm{~min} / \mathrm{h}$ treatment were not able to survive until the end of the 21 days of observation, whereas, in the treatment of $15 \mathrm{~min} / \mathrm{h}$ and $30 \mathrm{~min} / \mathrm{h}$ was capable to survive for 21 days. The same assumption also occurred in lipid productivity. The lipid productivity was not affected directly by the duration length of the paddle wheel machine, but it was affected by several variables such as the availability of nitrogen, but to continue the biosynthesis process of microalgae, it need the paddle wheel assistance to optimize the photosynthesis process.

\section{Conclusions}

Treatment of duration length using paddle wheel has no significant effect against the growth rate and lipid content of Nannoclhoropsis sp.. The paddle wheel stirring does not influence directly against the growth rate of Nannochloropsis sp., but it was very helpful in optimizing the photosynthesis process and survival rate of microalgae Nannochloropsis sp.. The dominant fatty acids for all treatment is Palmitic acid (saturated fatty acids), The best treatment to be applied based on the cost of electrical energy is $15 \mathrm{~min} / \mathrm{h}$.

\section{Acknowledgements}

I thank Dr. Ir. Mujizat Kawaroe, M.Si and Prof. Dr. Ir. Dietriech $G$ Bengen, DEA for guidance, critically reading the manuscript and helpful discussion. I also thank to Surfactan and Bioenergy Reasearch Center (SBRC - IPB).

\section{References}

Cassano, A. E., Martin, C.A., Brandi, R.J., Alfano, O.M.. 1995. Photoreactor analysis and design: fundamentals and applications. Industrial and Engineering Chemistry Research 34: 2155-2201.

Chisti, Y. 2007. Biodiesel from Microalgae. Biotechnology Advances 25: 294-306.

Chiu, S.Y., Kao, C.Y., Tsai, M.T., Ong, S.C., Chen, C.H., Lin, C.S. 2009. Lipid accumulation and $\mathrm{CO} 2$ utilization of Nannochloropsis oculata in response to $\mathrm{CO}_{2}$ aeration. Bioresource Technology $100: 833-838$.

Gudin, C., Chaumont, D. 1991. Cell fragility The key problem of microalgae mass production in closed photobioreactors. Bioresource Technology 38: 145-151

Hu, Q., Sommerfeld, M., Jarvis, E., Ghirardi, M., Posewitz, M., Seibert, M., Darzin, A. 2008. Microalgal triacylglycerols as feedstocks for biofuel production: 
perspectives and advances. Plant Journal 54: 621-639.

Kawaroe, M., Prartono, T., Sunuddin, A., Wulan Sari, D., Augustine, D. 2010. Mikroalga Potensi dan Pemanfaatannya untuk Produksi Bio Bahan Bakar. Bogor: IPB Press.

Kawaroe, M., Hwangbo, J., Agustine, D., Putra, H. A.. 2015. Comparison of density, specific growth rate, biomass weight, and doubling time of microalgae Nannochloropsis sp. cultivated in Open Raceway Pond and Photobioreactor. AACL Bioflux 8 (5): 740-750.

Kawaroe, M., Prartono, T., Saefurahman, G.. 2015. Kepadatan dan Laju Pertumbuhan Spesifik Nannochloropsis sp. pada Kultivasi Heterotropik Menggunakan Media Hidrolisat Singkong. OmniAkuatika 11 (2) : 15-19.

Khozin-Goldberg, I., Shrestha, P., Cohen, Z., 2005. Mobilization of arachidonyl moieties from triacylglycerols into chloroplastic lipids following recovery from nitrogen starvation of the microalga Parietochloris incisa BBA Molecular and Cell Biology of Lipid 1738: 63-71.

Klok, A.J., Martens, D.E., Wijffels, R.H., Lamers, P.P. 2013. Simultaneous growth and neutral lipid accumulation in microalgae. Bioresource Technology 134: 233-243.

Lavens, P., Sorgeloos, P. 1996. Manual on the Production and Use of Live Food for Aquaculture. FAO Fisheries Technical Paper.No. 361.Food and Agriculture Organization of the United Nations. Rome

Mattjik, A., Sumertajaya, M. 2002. Rancangan Percobaan dengan Aplikasi SAS dan Minitab Jilid 1. IPB Press. Institut Pertanian Bogor. Bogor.

Reynolds, C.S. 1990. The Ecology of Freshwater Phytoplankton.Cambridge University Press. Cambridge.

Steel, R.G.D., Torrie, J.H. 1989. Prinsip dan Prosedur Statistika. Edisi Kedua. PT. Gramedia. Jakarta.

Vasquez-Duhalt, R., Arredondo-Vega, B.Q. 1991. Oil Production From Microalgae Under Saline Stress. Biomassa For Energy and Industry 5 th E.C. Conference, vol 1: Policy, Environment, Production and Harvesting, 1:547-551.

Vincenti, W.G., Kruger C.H.. 1965. Introduction to physical gas dynamics, Wiley, New York. 535p.

Wood, A.M., Everroad, R.C., Wingard, L.M.. 2005. Measuring growth rates in microalgal cultures. In: Andersen, R.A. (Ed.), Algal Culturing Techniques. Elsevier Academic Press, pp. 269-285. 